\title{
Rectoprotomarssonella n. gen., a new agglutinated foraminiferal genus from the Upper Cretaceous of the Carpathian Flysch
}

\author{
Michael A. Kaminski ${ }^{1}$, Miroslav Bubík ${ }^{2}$, and Claudia G. Cetean ${ }^{3}$ \\ ${ }^{1}$ Department of Earth Sciences, University College London, Gower Street, London WC1E 6BT, U.K. \\ email:m.kaminski@ucl.ac.uk; ceteanc@yahoo.com \\ ${ }^{2}$ Czech Geological Survey, Leitnerova St. 22, 65869 Brno, Czech Republic \\ email:bubik@cgu.cz \\ ${ }^{3}$ Department of Geology, Babeş-Bolyai University, M. Kogalniceanu 1, 400084, Cluj Napoca, Romania
}

\begin{abstract}
The new agglutinated foraminiferal genus Rectoprotomarssonella $\mathrm{n}$. gen. is characterized by its high trochospiral coiling with multiserial to uniserial chamber arrangement and solid, noncanaliculate wall with calcareous cement. This taxon shows close relationship to the Cretaceous genus Protomarssonella Desai and Banner, from which it differs in possessing a uniserial part. The type species is a stratigraphic indicator in Campanian to Maastrichtian deep-water sediments in the Western Tethys and North Atlantic.
\end{abstract}

\section{INTRODUCTION}

The species "Goessella" rugosa (Hanzlíková) is a well-known stratigraphically important species in Upper Cretaceous deepwater sediments of the Western Tethys and North Atlantic, and serves as a zonal indicator in several zonal schemes (Neagu 1968; Geroch and Nowak 1984; Kuhnt et al. 1992; Neagu et al. 1992; Kuhnt and Kaminski 1997). The species was originally described as a species of Marssonella, and was later transferred to the genus Goesella by Hanzlíková (1969). However, the type species of Goesella is a modern form described from the Philippine Sea (Cushman 1913), characterized by a test wall perforated by canaliculae (Loeblich and Tappan 1987). Moreover, the stratigraphic range of Goesella was reported by Loeblich and Tappan (1987) as "Eocene-Recent", and reports of this genus in the Campanian were therefore deemed enigmatic.

The purpose of this study is to examine the wall structure of the largely isomorphic Campanian to Maastrichtian taxon formerly attributed to Goesella in order to more precisely determine its systematic affinities.

\section{STUDIED MATERIALS}

We used both archive material and specimens from newly collected samples to illustrate the morphology of the type species, Marssonella rugosa Hanzlíková 1953. We made an effort to locate the type specimens of Marssonella rugosa in the Hanzlíková Collection in the Czech Geological Survey, and made enquiries as to the whereabouts of type specimens of is junior synonym, Goesella carpathica Liszkowa 1959. Unfortunately, no primary type specimens of either species could be found. New specimens examined in this study derive from lower Maastrichtian marls from the Subsilesian Unit of the Polish Carpathians that outcrop in Węglówka, Poland. Samples were collected in the stream that flows alongside the main road at the entrance to the village. The Węglówka locality was described in detail by Huss (1966) and by Ślączka and Kaminski (1997).

\begin{abstract}
METHODS
To investigate wall structure, we used methods outlined by Desai and Banner (1987). Concentrated $\mathrm{HCl}$ was carefully applied to the outer test wall of a specimen with a picking brush in order to dissolve the cement of the outer agglutinated layer and reveal any possible canaliculate structure. The specimens were then rinsed in distilled water, mounted on stubs, and photographed in SEM. Photographed specimens are housed in the Micropalaeontological Collections of University College London.
\end{abstract}

\section{SYSTEMATIC TAXONOMY}

Suborder VERNEUILININA Mikhalevich and Kaminski 2004 Superfamily VERNEUILINACEA Cushman 1911 Family PROLIXOPLECTIDAE Loeblich and Tappan 1985

Rectoprotomarssonella Kaminski, Bubík, and Cetean n.gen.

Type species: Marssonella rugosa Hanzlíková, in Homola and Hanzlíková 1953 (monotypic)

Description: Test large, elongate, up to $1 \mathrm{~mm}$ in length, tapering toward the base, and later nearly cylindrical in section, with a flattened terminal face. Early stage trochospirally coiled with four to five chambers per whorl, later reduced to triserial, biserial, and finally uniserial. Chamber interior not subdivided. Sutures mostly indistinct, slightly depressed. Wall coarsely agglutinated, noncanaliculate, with sparse calcareous cement, comprised of coarse particles held in a fine-grained groundmass. Aperture initially interiomarginal, a low slit situated in a re-entrant at the base of the last chamber, moving to terminal position in the uniserial part, rounded, without a tooth. Campanian-Maastrichtian; Carpathians (Poland, Czech Republic, Romania); Spain.

Remarks: This genus differs from Protomarssonella Desai and Banner 1987 in possessing a uniserial part. It differs from the Cenozoic genus Goesella in having a solid wall and in lacking any trace of an apertural tooth. 


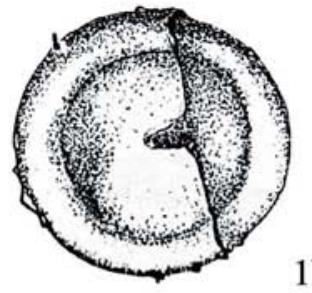

Ib

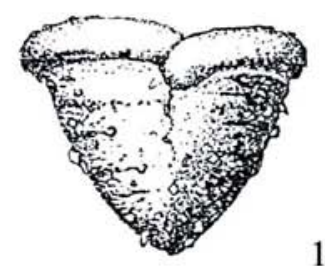

1a
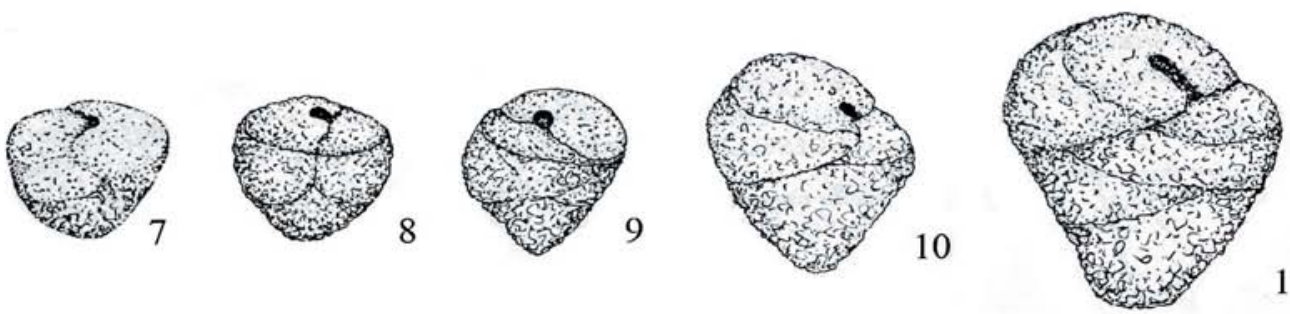

11
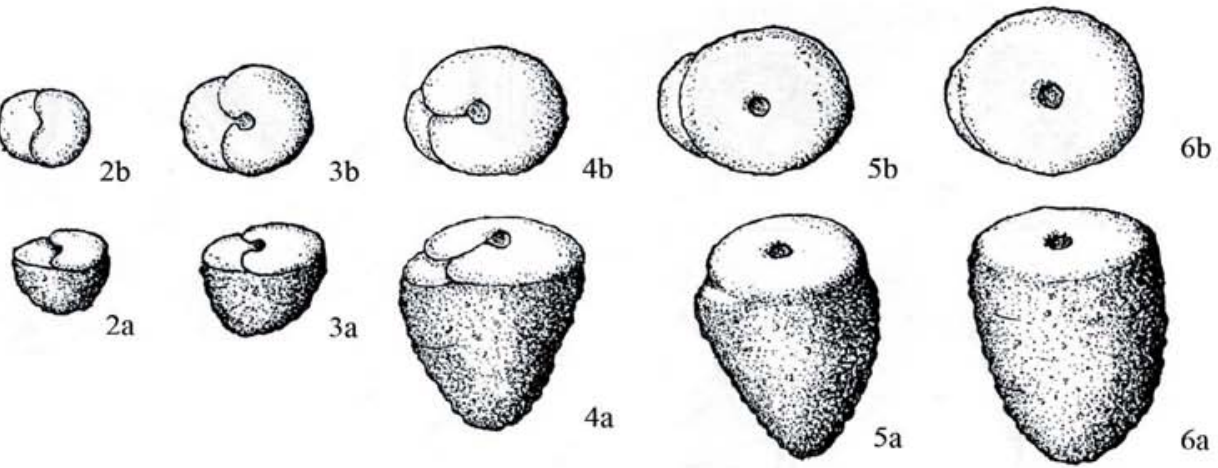

$6 a$

TEXT-FIGURE 1

Original illustrations of the type species of Rectoprotomarssonella n. gen., from the Carpathian Upper Cretaceous. 1a,b. Holotype of Marssonella rugosa, from Hanzlíková (1953), ×110; 2a-6b. Type specimens of Goesella carpathica from Liszkowa (1959), holotype not indicated, ×14; 7-12. Specimens of $R$. rugosa from the southern Carpathians, from Neagu (1968), $\times 45$.

Derivation of name: With reference to the fact that this genus possesses a uniserial part.

\section{Rectoprotomarssonella rugosa (Hanzlíková 1953)}

Plate 1, figures 1-9e, Text-figure 1

Marssonella rugosa Hanzlíková, in HOMOLA and HANZLÍKOVÁ 1953, p. 395, pl. 2, figs 5, 7.- MORGIEL and OLSZEWSKA 1981, p. 22, pl. 5, fig. 18 .

Goësella carpathica Liszkowa 1959, p. 60, pl. 3, fig. 9a-f. - NEAGU 1968, p. 238, pl. 1, figs 16-21. - NEAGU 1970, p. 45, pl. 7, figs 25-30. Goesella rugosa (Hanzlíková). - HANZLÍKOVÁ 1969, p. 24, fig. 19 [n.comb.]. - HANZLÍKOVÁ 1972, p. 59, pl. 12, fig. 5. - GEROCH and NOWAK 1984, pl. 4, figs 8, 13, 18. -KUHNT and KAMINSKI 1990, p. 469, pl. 5, figs k-m. - KUHNT and KAMINSKI 1997, pl. 7, figs a,b.

Description: Test large, elongate, up to $1 \mathrm{~mm}$ in length, tapering toward the base, and later nearly cylindrical in section, with a flattened terminal face. Early stage trochospirally coiled with about five chambers per whorl, later reducing to triserial, biserial, and finally uniserial, with as many as four uniserial chambers. Chamber interiors simple. Sutures mostly indistinct, only slightly depressed. Wall coarsely agglutinated, noncanaliculate, with sparse calcareous cement, comprised of coarse detrital particles held in a fine-grained groundmass. In places large grains protrude from the peripheral surface of the test. Apertural face more finely agglutinated, lacking protruding larger grains. Aperture initially interiomarginal, a low slit situated in a re-entrant at the base of the last chamber, moving to an areal position in the biserial part, and finally to terminal position in the uniserial part, rounded, in a slight depression, without a tooth.
Remarks: Acid treatment of the exterior wall reveals a solid wall texture, with no sign of canaliculae. Acid treated specimens display holes in the wall where calcareous grains have been dissolved away, but no sign of a regular pattern of rounded pseudopores, as in the genus Marssonella (see Desai and Banner 1987). The presence of sparse larger grains interspersed in the peripheral wall is a characteristic feature of this species. Where larger grains appear, the wall is only a single grain thick.

Only rare specimens have a well-developed uniserial part, a fact already noted by Hanzlíková (1969). In fact, the specimens illustrated by Hanzlíková $(1953,1969)$ were all terminally biserial. Our specimens from Węglówka mostly possess only one or two uniserial chambers, and our largest specimen has four uniserial chambers. Even if no uniserial specimens are present in a population, the species can still be distinguished from other Protomarssonella species by its larger dimensions and by its characteristic wall texture, with coarse grains protruding from the lateral chamber wall. The first chambers of the uniserial part still display some aspect of biseriality, and can be described as "lax-uniserial", while later chambers are truly uniserial, with horizontal sutures.

Hanzlíková (1969) also regarded the Paleocene species Dorothia beloides Hillebrandt 1962 to be synonymous with this species. We do not agree with this view, as $D$. beloides is much narrower than $R$. rugosa and has a long biserial portion that does not become uniserial. Furthermore, $D$. beloides ranges to the end of the Paleocene, whereas $R$. rugosa is largely confined to the Cretaceous. 
Occurrence: This species has been reported as "Goesella rugosa" or as "Goesella carpathica" from numerous localities in the Czech, Polish, and Romanian Carpathians, as well as from localities outside the Carpathians. Liszkowa (1959) regarded the species as "characteristic" for the Campanian-Maastrichtian Subsilesian Series of the Polish Carpathians, recording it from several localities (Bachowice, Wadowice, Bielsko, Wieliczka, Tarnów, Sanok). Neagu (1968) established a "Goesella carpathica Zone" for the lower to middle Campanian of the Teleajen Nappe in the Romanian Carpathians. In the Zumaya section of northern Spain, the species has been reported to range from the lower Campanian to the lowermost Danian, with its maximum abundance in the lower to middle Campanian (Kuhnt and Kaminski 1997). It has also been found in the Campanian-Maastrichtian of the Subbetic Unit of southern Spain (Kuhnt and Kaminski 1990).

Type locality: This species was first described by Hanzlíková (1953) from surface outcrops of the Púchov Marls (Couches Rouges facies) in Hluk, Czech Republic. Hanzlíková (1969, 1972) later reported it from the Maastrichtian (A. mayaroensis Zone) of the Frydek Formation of the Subsilesian-Zdanice Unit at its type locality in Frýdek-Mistek, Czech Republic. The junior synonym, Marssonella carpathica, was described by J. Liszkowa (1959) from the Subsilesian Unit of the Polish Carpathians. The samples studied by J. Liszkowa were collected by Prof. Marian Książkiewicz from trenches dug in the forest about $1 \mathrm{~km}$ above the church in the village of Bachowice, Poland (M. Cieszkowski, personal communication, 2007). In summer 2007, we searched the forest near Bachowice, but unfortunately no outcrops were found.

Type specimens: A single slide labelled "Goesella rugosa, Holotype" is preserved in the Hanzlíková Collection in the Czech Geological Survey (text-fig. 2). Unfortunately, this slide does not contain the specimen drawn by Hanzlíková (1953), and the locality written on the slide (Frydek beds, Žukov NP-15 borehole) does not agree with the locality given in the original description of the species. The slide was obviously made at a later date and the label "Holotype" was added to the slide mistakenly. In our opinion, this specimen has only metatype status (a specimen from a different locality identified by the author of the species at some later date).

The whereabouts of the Liszkowa collection are still unknown, and the collection is presumed lost. Janina Liszkowa was employed at the Polish Geological Institute, Carpathian Branch, and only very few slides made by her are preserved in the collections (Barbara Olszewska, personal communication, 2007), none of which are from her Bachowice study (Liszkowa 1959). Her husband, Stanisław Liszka, was employed at the AGH University of Science and Technology in Krakow, but an extensive search of the AGH micropalaeontological collections did not uncover any slides prepared by Janina Liszkowa (Michał Krobicki, personal communication, 2007). We likewise searched the collections of Stanisław Geroch at the Institute of Geological Sciences, Jagiellonian University, for samples from Bachowice, without results (J. Liszkowa collaborated with S. Geroch, and there was the possibility that they exchanged samples). In her retirement, Janina Liszkowa worked from her home in Kraków, and we assume her collection was disposed of shortly after her death.

\section{DISCUSSION}

The taxonomic revision of the stratigraphically-important species Marssonella rugosa was initially hampered by the lack of

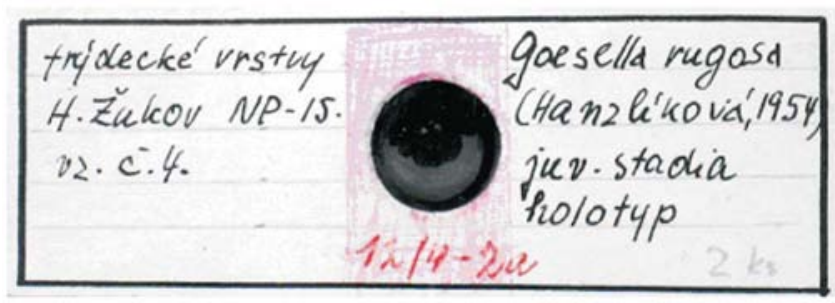

TEXT-FIGURE 2

The "false holotype" slide from the Hanzlíková collection, Czech Geological Survey, Prague.

archived type specimens. The types of both $M$. rugosa and $M$. carpathica have not been preserved. Nevertheless, the species concept of these species is well-established, so according to Article 75.2 of the ICZN, there is no need to designate a neotype. Fortunately, the species can be found at numerous localities in the Carpathians, mostly in the marly Campanian-Maastrichtian Subsilesian-Zdanice facies.

Our observation of the solid, non-canaliculate wall structure of this species implies closer relationship to the Cretaceous genus Protomarssonella rather than to the Recent genus Goesella. It is more probable that the genus Rectoprotomarssonella is simply derived from a terminally biserial species such as Protomarssonella crassa (Marsson) by phylogenetic size increase that eventually resulted in the formation of a terminally uniserial part.

\section{ACKNOWLEDGEMENTS}

We thank our colleagues Barbara Olszewska (PIG) and Michał Krobicki (AGH) for their kind efforts in attempting to locate the types of Goesella carpathica, and Marek Cieszkowski (AGH) for information on the type locality. Valeria Mikhalevich (RAS) and Jarosław Tyszka (PAN) kindly pre-reviewed the paper. The revision of agglutinated foraminiferal genera is supported by a consortium of oil companies (BP, PDVSA, Saudi Aramco, Shell, Total, RPS Energy, Fugro Robertson). This is contribution nr. 82 of the Deep-Water Agglutinated Foraminiferal Project.

\section{REFERENCES}

CUSHMAN, J.A., 1913. New Textulariidae and other arenaceous foraminifera from the Philippine Islands and contiguous waters. Proceedings of the United States National Museum, 44: 633-638.

DESAI, D. and BANNER, F.T., 1987. The evolution of Early Cretaceous Dorothiinae (Foraminiferida). Journal of Micropaleontology, 6(2): 13-27.

GEROCH, S. and NOWAK, W., 1984. Proposal of Zonation for the late Tithonian - late Eocene, based upon arenaceous foraminifera from the outer Carpathians, Poland. In: Oertli, H., Ed., Benthos ' 83 ; 2nd International Symposium on Benthic Foraminifera Pau (France), April 11-15, 1983, pp. 225-239. Pau and Bourdeaux: Elf Aquitaine, ESSO REP and TOTAL CFP.

HANZLÍKOVÁ, E., 1969. The foraminifera of the Frydek Formation (Senonian). Sborník geologických Věd, Paleontologie, 11: 7-84.

1953, Systematická čast. In: Homola, V. and Hanzlíková, E. 1953. Biostratigrafické, tektonické, a lithologické studie na Těšínsku. Sbornik Ustředního Ústavu Geologického, 21: 317-498. 
HUSS, F., 1966. Otwornice aglutynujące serii podślaskiej jednostki roponośnej Węglowki (Polskie Karpaty Fliszowe) [Agglutinated foraminifera of the oil-bearing subsilesian series in Węglówka (Polish Flysch Carpathians]. Prace Geologiczne, Polska Akademia Nauk, 34: 7-76.

KUHNT, W. and KAMINSKI, M.A., 1990. Paleoecology of Late Cretaceous to Paleocene deep-water agglutinated foraminifera from the North Atlantic and Western Tethys. In: Hemleben, C., Kaminski, M.A., Kuhnt, W. and Scott, D.B., Eds., Paleoecology, Biostratigraphy, Paleoceanography and Taxonomy of agglutinated foraminifera, 433-506. NATO ASI Series C, 327. Dordrecht: Kluwer Academic Press.

__ 1997. Cenomanian to lower Eocene deep-water agglutinated foraminifera from the Zumaya section, northern Spain. Annales Societatis Geologorum Poloniae, 67 (3-4): 257-270.

KUHNT, W., GEROCH, S, KAMINSKI, M.A., MOULLADE, M. and NEAGU, T., 1992. Upper Cretaceous Abyssal Claystones in the North Atlantic and the Western Tethys - Current Status of Biostratigraphical Correlation using Agglutinated Foraminifers. Cretaceous Research, 13: 467-478.

LISZKOWA, J., 1959. Mikrofauna warstw z egzotykami z Bachowic [Microfauna from beds with exotics from Bachowice]. Biuletyn Institutu Geologicznego, 131: 39-110 + 9 pls.
LOEBLICH, A.R. and TAPPAN, H., 1987. Foraminiferal genera and their classification. New York: Van Nostrand Reinhold Co., 970 pp.

NEAGU, T., 1968. Biostratigraphy of Upper Cretaceous deposits in the southern Eastern Carpathians near Brasov. Micropaleontology, 14: 225-241.

1970. Micropaleontological and stratigraphical study of the upper Cretaceous deposits between the upper valleys of the Buzau and Riul Negru Rivers (Eastern Carpathians). Memorii, Institutul Geologic, 12: 7-109. Bucarest.

NEAGU, T., PlAtON, E., DUMitResCU, G. and SELEA, L. 1992. The biostratigraphical significance of agglutinated foraminifera in the Eastern Carpathians (Upper Cretaceous). Analele Universităţii Bucureşti, 15-16: 45-49.

ŚLACZZKA, A. and KAMINSKI, M.A. 1998. Guidebook to Excursions in the Polish Flysch Carpathians - Field excursions for Environmental Geoscientists. Grzybowski Foundation Special Publication 6, $173 \mathrm{pp}$.

Manuscript received August 31, 2007

Manuscript accepted September 22, 2007

\section{PLATE 1}

1 The "false holotype" Hanzlíková collection, Czech Geological Survey, Prague, lateral view.

2 The "false paratype", Hanzlíková collection, Czech Geological Survey, Prague, 2a, lateral view, $2 b$, view of apertural end, $2 c$, initial end.

3 Topotype specimen from Hluk - Okluky, Czech Republic, Púchov Marls.

4-9 Specimens from Węglówka, Poland, Stream bank at entrance to village.

4 Specimen with four uniserial chambers.

5a,b Specimen with only two uniserial chambers, 5a, lateral view, 5 b, apertural view. Note central aperture in a shallow depression.
6-8 Terminally biserial specimens.

9 Specimen from the Radotruncana calcarata Zone, lower part of Upper Campanian, Plaiu Formation, Izlaz Valley, Coteneşti, southern Eastern Carpathians (Dâmboviţa Valley), Romania.

10 Specimen etched in $\mathrm{HCl}$ to expose wall structure. 10a, View of initial end, acid has opened up early chambers. 10b,c, Detail of wall, showing solid, noncanaliculate structure. $10 \mathrm{~d}$, lateral view of specimen, 10e, detail of wall, showing holes after calcareous agglutinated grains have been etched away. Specimen shows no sign of other perforations. 


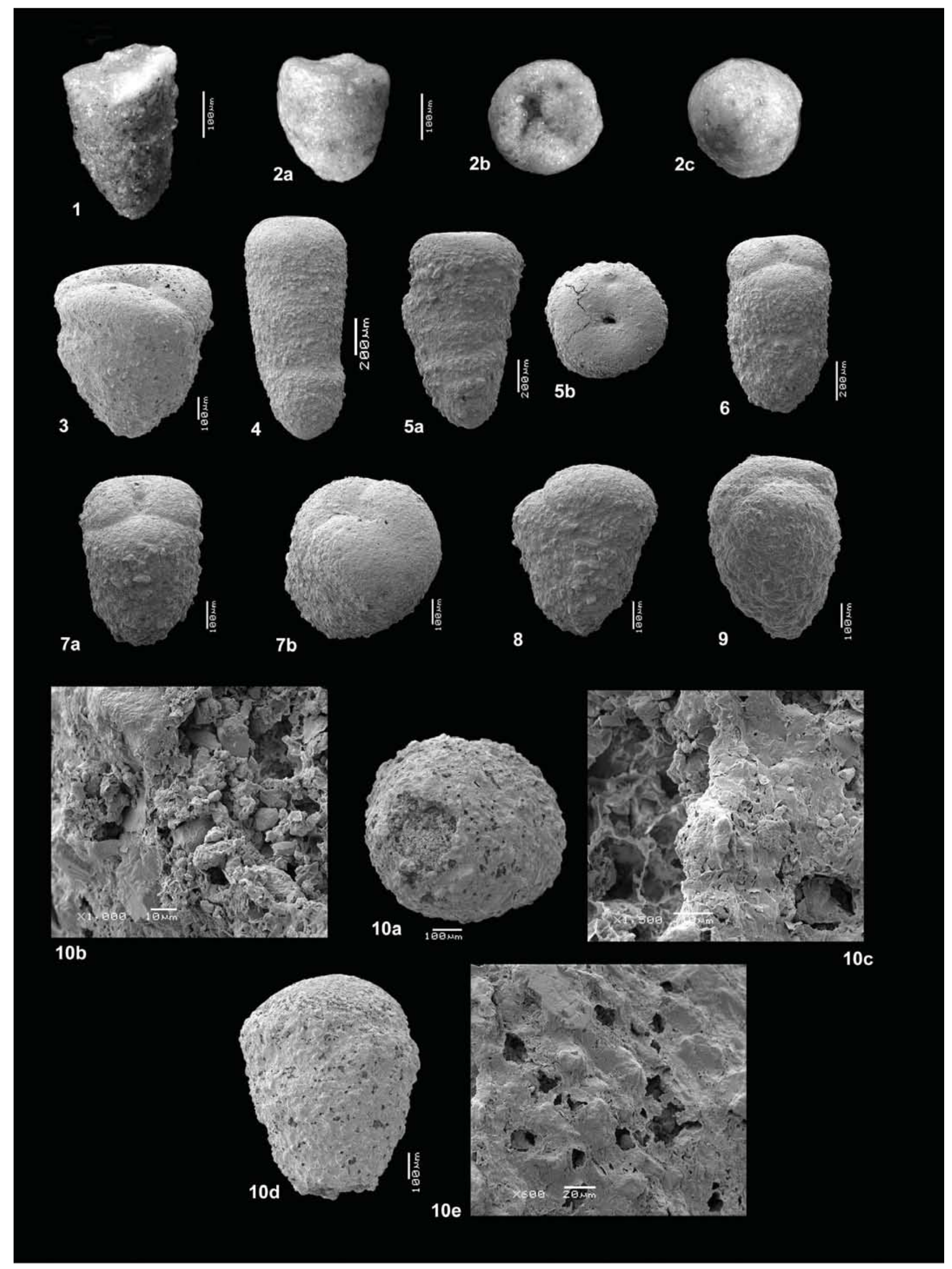




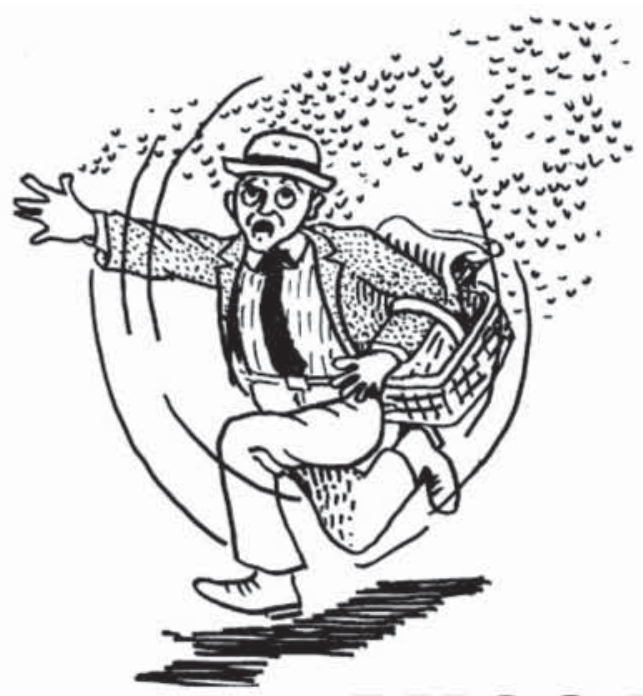

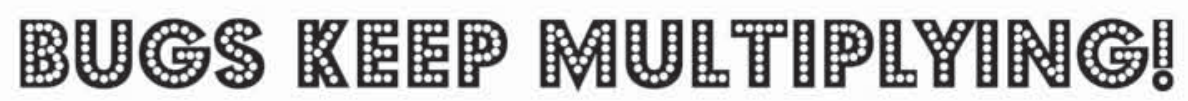

Just when we thought we had them nearly cleaned out of the literature, we're finding more!

Next year, the Catalogue of Foraminifera will get serious about finishing Irene McCullough's vast monograph, Qualitative observations on Recent Foraminifera with emphasis on the East Pacific. We processed around 400 of her new taxa between 1993 and 1996, but this was only a start -- there are some 2,000 remaining! They're everywhere! Of course, we can't afford to ignore the fossil taxa while we clean up the ocean floor, so this is going to take a while.

We have been doing all we can. McCullough's forams will be joining more than 48,000 others that we have extracted from the world literature in a relentless campaign going back to 1932.

And the Catalogue of Ostracoda? We are still digging out of the swarm of Chinese and Russian taxa that got into our library during the Glorious Worker years, with one monograph or peoples' team effort after another, all stuffed with new names. No telling when we'll get to the last of these, and we'll have to call in professional help because they all have to be translated first.

All those ostracodes will be packed in with the others we've gathered since 1954 -imagine, 25,000 ostracodes, and every one different! (If you don't believe us, look at the pictures.)

And still more! At the Catalogue of Diatoms, it was quiet and peaceful until somebody gave us access to a rare original copy of the Schmidt et al. Atlas der Diatomaceenkunde. Now we are faced with more than 2,500 type descriptions of new genera and species (and subspecies and varieties and forms) from the 480 plates of the Atlas, all of which have to be chased down, verified, and put in the Catalogue. It just never ends!

Although we started late with the diatoms, when we're done with Schmidt and friends we'll have scooped up more than 11,000. Greville, Hustedt, and Pantocsek already had quite a few.

We'll just have to roll up our sleeves and keep stuffing these creatures into the computer, with no sign of an end to them. For those that love the results, subscribing to the Ellis and Messina Catalogues has never been easier. Just go to the website at www.micropress.org and click on the price of your subscription, to pay online with credit card, PayPal or direct bank transfer. "Catbox" DVD backup comes free with internet access for the year, and supplement pages (for old-timers with printed sets) are also free with subscription. 